\title{
Crown and regeneration responses to silviculture systems in Pine and Sal forests: preliminary results from silviculture trials in Mid-hills Nepal
}

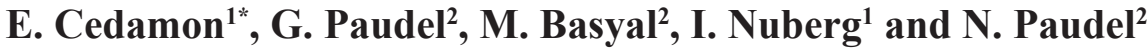

Silviculture trial plots were established in Kavre and Lamjung districts by the EnLiFT Project (Enhancing livelihoods and food security through improved agroforestry and community forestry in Nepal) to examine stand response to selected silviculture systems - uniform shelterwood, selection system, and negative thinning and as a showcase to forest users for these silviculture systems. This paper analyses the extent of canopy gaps on these trial plots after one-year of application of silviculture treatments and regeneration development. Using crown photographs, crown cover was estimated and compared between silviculture systems. The analysis showed that rigid silviculture systems like shelterwood and selection systems created canopy gap larger than negative thinning in Pine plantations and the rate of natural regeneration was directly related with the canopy gap. However, in Shorea robusta-CastanopsisSchima (Sal-Katus-Chilaune) forest, negative thinning created canopy gap larger than selection system due to removal of 4-D trees, majority of trees were Schima wallichii (Chilaune),which typically have large spreading crown. Although, it may be too early to conclude the relationship between regeneration development and canopy gap from the trial plots, it became clear that silviculture operations have significant role in promoting higher regeneration. Selection and shelterwood systems are better than current silviculture regime represented by negative thinning in this study.
\end{abstract}

Key words: Canopy gaps, community forestry, multiple-use forestry, selection, shelterwood

Covis ommunity forestry was initiated in several developing countries primarily to reverse land degradation (Gilmour, 2016; Dressler et al., 2010). Community development and livelihood outcomes were initially perceived as secondary outcome but has become a dominant objective gaining national governments and international community (Gilmour, 2016). While the contribution of community forestry in improving forest cover, social cohesion and rural income (Padgee et al., 2006; Charnley and Poe, 2007; Antinori and Rausser, 2008; Chhetri et al., 2013), globally community forestry has underperformed, or community forestry goals are rarely achieved (Sunderlin, 2005; Maryudi et al., 2012). Several authors have argued that a key success factor for community forestry is its ability to provide early and regular supply of materials to forest users (Calderon and Nawir, 2006; Pokharel, 2012).

The Government of Nepal is strongly campaigning for commercialisation of forest management through scientific forest management to meet the country's demand for timber and fuelwood (MFSC, 2016). The Department of Forests (2015) promotes active silvicultural programmes such as shelterwood $^{3}$ and selection silviculture systems or modification of these silviculture systems as approaches for scientific forest management. Generally, it is understood that any silviculture system involves harvesting of overstorey trees either singly or in groups to promote tree regeneration (O'Hara, 2002), there is a lack of understanding on regeneration development following harvesting or silviculture treatments on community forests in Mid-hills of Nepal. To address the lack of silviculture understanding, the EnLiFT Project ${ }^{4}$ embarked on a silviculture trials to demonstrate seed tree and selection silviculture

\footnotetext{
School of Agriculture, Food and Wine, The University of Adelaide, Waite Campus, Urrbrae, South Australia;

*E-mail: edwin.cedamon@adelaide.edu.au

Forest Action Nepal, Bagdole, Lalitpur, Nepal

3 Shelterwood system as described in the Scientific Forest Management Guideline is actually a seed tree system, this term is however adopted in the trials to be consistent with Department of Forests terminology.
} 
systems and to examine forest ecological and forest users' responses on these systems. The aim of this paper is to report the extent of canopy gaps and regeneration development in these trial plots after one-year of implementation of silviculture treatments.

Gaps on forest canopy represent opportunities for forest regeneration and had been studied widely (O'Hara, 2014) but has been used little by foresters in developing silviculture regimes (Coates and Burton, 1997). The interest in understanding forest gaps in silviculture is due to opportunities it presents for wider range of forest management objectives including resilience and adaptability (Kern et al., 2016). Typical silvicultural regimes developed based solely timber-centred attributes present some challenges when applied in community forests due to diverse forest management objectives including commercial and subsistence demand for timber and non-timber forest products and environmental conservation(Cedamon et al., 2016). For example, when the aim of forest management is increasing fodder and forest litters, silviculture programme may need to consider size and frequency of forest openings so that fodder and litter production is supported. The EnLiFT silviculture trial plots, therefore, present opportunities for examining regeneration development, growth and survival of planted fodder species given canopy gaps resulting from different silviculture treatments.

The EnLiFT Project established silviculture trial plots in Chaubas and Dhunkharka village development committees (VDCs) in Kavre district and in Tandrang Taksar VDC in Lamjung district. The purpose of the silviculture trials is two-fold. First, the trial plots were established as a learning site for community forest user groups on how to implement a number of silviculture systems potential for application in their community forests. Secondly, the trial plots serve as experiments where tree and stand response can be measured to guide development of silviculture regimes for active and equitable community forest management. This paper reports the crown cover and natural regeneration development in the silviculture trial plots from Chaubas and Tandrang Taksar representing Pine plantation and naturally regenerated Sal forests, respectively.
Crown cover and regeneration development in Dhunkharka VDC is not reported, as the treatments were applied late in one plot.

\section{Materials and methods}

\section{Study area}

The silviculture trial plots in Chaubas VDC are located in the Chapani community forest. The plantation has an area of 85 ha dominated by about 35-years old Gobre (Pinus wallichiana) and Patle Salla (Pinus patula). The silviculture trial plots in Tandrang Taksar VDC are in Lampata community forest which is a Shorea robustaSchima wallichii (Sal-Chilaune) with a total forest area of $50 \mathrm{ha}$. These forests are managed for timber, firewood, fodder and leaf litter. However, they are, generally, undermanaged due to strong conservation ethos and lack of silviculture skills of forest users. To address this gap, handson trainings on silviculture management were provided to participating community forest user groups. The trial plots served as a participatory research site where observations on the tree and forest response to silviculture systems are collaboratively undertaken by EnLiFT researchers and forest users.

In Chapani community forest, four trial plots were established each having a dimension of $60 \mathrm{~m} \mathrm{x}$ $70 \mathrm{~m}$. In Lampata community forest, three trial plots were established each having a dimension of $50 \mathrm{~m} \mathrm{x} 80 \mathrm{~m}$. The treatments are described in table 1. Some trees were felled in each plot following single tree selection system based on $\mathrm{dBq}$ approach ${ }^{5}$, shelterwood system following Nepal Scientific Forest Management Guideline 2015 and cutting dead, dying, deformed, and diseased (4-D) trees. The pre and post-treatment tree density and the volume of timber harvested from the trial plots are provided in table 1. After silviculture treatment applied, the forest floor was cleared by removing debris and weeds to prepare the ground for regeneration. In Chapani $\mathrm{CF}$, the silviculture treatments were applied from April to May, 2015 and the seedling count was made in January 2017, whereas the silviculture treatments were applied from January to March 2016 in Lampata CF and the seedling count was made in January 2017.

\footnotetext{
${ }^{4}$ EnLiFT Project is an action research project funded by Australian Centre for International Agricultural Research (ACIAR). The aim of the project is to enhance food security and livelihood through improved agroforestry and community forestry in Nepal.

5 Q-factor is diminution quotient for a negative exponential function typical for a balanced uneven-stand. It is expressed as the $\mathrm{q}=\mathrm{Ni} \div \mathrm{Ni}+1$. The $\mathrm{DBq}$ approach which builds upon decisions on upper diameter class for which the number of trees has to be retained (d), a desired basal area (B) and a q-factor (q).
} 
Table1:Tree density in pre and post-treatment and volume harvested due to silviculture treatment in Chapani and Lampata CFs

\begin{tabular}{|c|c|c|c|}
\hline Silviculture treatments & $\begin{array}{l}\text { Pre-treatment } \\
\text { tree density } \\
\text { (stems per } \\
\text { hectare) }\end{array}$ & $\begin{array}{c}\text { Post-treatment } \\
\text { tree density } \\
\text { (stems per } \\
\text { hectare) }\end{array}$ & $\begin{array}{l}\text { Volume harvested } \\
\text { due to silviculture } \\
\text { treatment }\left(\mathrm{m}^{3} / \mathrm{ha}\right)\end{array}$ \\
\hline \multicolumn{4}{|l|}{ 1. Chapani CF- Chaubas, Kavre } \\
\hline Negative thinning - harvesting 4D trees only & 416 & 283 & 60 \\
\hline $\begin{array}{l}\text { Single tree selection for mixed Pine and } \\
\text { broadleaf timber production - using dBq }\end{array}$ & 504 & 185 & 300 \\
\hline $\begin{array}{l}\text { Single tree selection for timber-fodder forest } \\
\text { garden - using } \mathrm{dBq}\end{array}$ & 535 & 147 & 200 \\
\hline $\begin{array}{l}\text { Uniform shelterwood system - using the SFM } \\
\text { guideline } 2015\end{array}$ & 361 & 50 & 243 \\
\hline \multicolumn{4}{|l|}{ 2. Lampata - TandrangTaksar, Lamjung } \\
\hline Negative thinning - harvesting 4D trees only & 1412 & 1167 & 38 \\
\hline $\begin{array}{l}\text { Single tree selection for timber production - } \\
\text { using } \mathrm{dBq}\end{array}$ & 953 & 780 & 173 \\
\hline $\begin{array}{l}\text { Single tree selection for timber-fodder forest } \\
\text { garden - using } \mathrm{dBq}\end{array}$ & 1253 & 963 & 52 \\
\hline
\end{tabular}

Trees were measured jointly by EnLiFT and Forest user Groups (FUGs) following the Rapid Silviculture Appraisal Technique described by Cedamon et al. (2016) before the silviculture treatments applied to estimate timber stock and derive stand table. The timber stock table was used by the FUG to apply for harvesting permit while the stand table was used in participatory and bilateral dialogues aimed at collaboratively determining silviculture systems appropriate for the given forest characteristics. Tree measurement data included diameter at breast height, species local name, total tree height, and crown radii. Eight photographs of the canopy were taken from corners of $10 \mathrm{~m} \times 10 \mathrm{~m}$ sub- plots within the plot at $57.5^{\circ}$ from the zenith ordinary (without hemispherical lens) using digital cameras to obtain estimate of canopy cover. Canopy cover is defined in this study as the proportion of the forest floor covered by the vertical projection of the tree crowns (Jennings et al., 1999). Canopy photographs were processed using CanEYE software (freely downloadable from https:// www6.paca.inra.fr/can-eye/Download) to estimate canopy cover. Canopy gaps are then estimated as 100- crown cover (\%) because this value is more appreciated by forest users particularly in terms of regeneration development.
Seedling count was made in $1 \mathrm{~m} \times 1 \mathrm{~m}$ sub-plots located within the trial plots spaced at $10 \mathrm{~m} \times 10$ $\mathrm{m}$ grid. In Lampata, each trial plot has 28 seedling sub-plots while Chapani trial plot has 30 seedling sub-plots. All seedlings within the sub-plots which include saplings below $5 \mathrm{~cm}$ diameter at breast height (dbh) are counted and species name recorded. These sub-plots were marked with timber sticks for future re-measurement.

\section{Results and discussion}

\section{Canopy gaps created by silvicultural regimes}

It is generally understood that forest canopy determines the micro-habitat within the forest controlling the recruitment and growth of new plants and animal activities. All silviculture activities alter forest canopy and stand structure to some degree necessary for improving health and growth of existing forest and development of future forests. The EnLiFT silviculture trial plots showed that different silviculture systems created a different canopy profiles as measured by canopy gaps and that these differences were more evident in Pine plantation than that in naturally regenerated Sal.

In Chapani forest, which is an even age Pine plantation, the average canopy gap before applying silviculture treatment was between 
34-44\%. Negative thinning increased the canopy gap by about $11 \%$, selection silviculture for fodder-timber forest garden increased the gap by $28 \%$, and selection system for timber production increased the canopy gap by $24 \%$, while shelterwood system increased the gap by $43 \%$ (Table 2). The differences on canopy gap on timing of measurements (before and after silviculture treatment) and between silviculture treatments was found to be statistically significant based in analysis of variance (ANOVA) where $p$ value is 0.000 . There was also a significant interaction $(p$ value $=0.000$ ) between timing of measurement and silviculture treatments indicating that differences of canopy gaps that some silviculture treatments resulted in considerably larger canopy gaps than others. As shown in table 2, negative thinning retained more than half of crown cover, selection silviculture retained $28-40 \%$ of crown cover, while shelterwood retained $14 \%$ of crown cover.

A relatively different canopy gap profile has been found in naturally regenerated Sal forest in Lampata community forest. As shown in table 2, the average canopy gap before applying silviculture treatments ranged from 7-9\%, while after applying silviculture treatment it ranged from $48-53 \%$ across treatments. Canopy gap increased by $45 \%$ in negative thinning, while it increased by $38 \%$ in selection silviculture system for fodder-timber forest garden and $41 \%$ for timber production. Canopy gaps before and after silviculture treatments are significant while the differences in canopy gaps between treatments are not ( $p$ value $=0.072$ ), indicating that generally negative thinning and selection silviculture have the same effects on canopy gaps creation on naturally regenerated Sal stands.

\section{Relationship between canopy gap and natural regeneration}

Following silviculture operations, a survey was undertaken on seedlings in the trial plots. It was found that only $23 \%$ of the seedling sub-plots had regeneration in Chapani Pine plantation while it was $100 \%$ for selection silviculture for fodder-timber forest garden. The seedling density varied on an average of 26,000 to 423,000 per ha in Pine plantation. In Sal-Chilaune forest, $79 \%$ to $100 \%$ of sub-plots had regeneration and the seedling density was in a range of 52,000 to 93,000 per ha (Table 3). It is notable, however, that for Pine plantation, seedling occurrence was higher in selection silviculture plot where fodder was planted and lower in negative thinning trial plot. Although all plots were subjected to the same level of weed slashing and debris removal after harvesting, the fodder-timber selection plot had almost twice the number of regeneration than the shelterwood plot although it had slightly lower average canopy gap. In Lampata trial plots, negative thinning had the lowest seedling density among the three plots while fodder-timber selection plot had the highest seedling density.

Table 2: Canopy gap (\%) before and after silviculture treatments in Chapani and Lampata community forests in Mid-hills districts

\begin{tabular}{lcccc}
\hline \multirow{2}{*}{\begin{tabular}{l} 
Silviculture treatment \\
\cline { 2 - 4 }
\end{tabular}} & \multicolumn{3}{c}{ Canopy gap (\%) } \\
\cline { 2 - 5 } & Before silviculture treatment & After silviculture treatment \\
\cline { 2 - 5 } Chapani CF & Mean & S.E. of Mean & Mean & S.E. of Mean \\
\hline Negative thinning & 34.31 & 1.36 & 45.28 & 2.19 \\
Selection for fodder -timber forest garden & 44.31 & .99 & 72.27 & 2.96 \\
Selection for timber & 35.65 & 1.20 & 59.39 & 2.51 \\
Shelterwood & 44.07 & 1.13 & 85.59 & 1.96 \\
Lampata CF & & & & 1.96 \\
Negative thinning & 7.75 & .52 & 52.83 & 1.41 \\
Selection for fodder -timber forest garden & 9.26 & .97 & 46.99 & 1.90 \\
Selection for timber & 6.78 & .38 & 47.96 & \\
\hline
\end{tabular}


Table 3: Regeneration occurrence, seedling density and canopy gaps for silviculture treatments in Chapani and Lampata community forests

\begin{tabular}{lccc}
\hline \multicolumn{1}{c}{ Silviculture treatment } & $\begin{array}{c}\text { Proportion of } \\
\text { regeneration } \\
\text { sub-plots with } \\
\text { seedlings (\%) }\end{array}$ & $\begin{array}{c}\text { Seedling } \\
\text { density } \\
\text { (seedlings per } \\
\text { hectare) }\end{array}$ & $\begin{array}{c}\text { Average canopy } \\
\text { gap after } \\
\text { silviculture } \\
\text { treatment(\%) }\end{array}$ \\
\hline Chapani trial plots & & & 45.3 \\
Negative thinning & 0.23 & 26,000 & 72.3 \\
Selection for fodder -timber forest garden & 1.00 & 423,667 & 59.4 \\
Selection for timber & 0.53 & 54,000 & 85.6 \\
Shelterwood & 0.97 & 223,667 & 52.83 \\
Lampata trial plots & 1.00 & 52,857 & 46.99 \\
Negative thinning & 0.86 & 91,786 & 47.96 \\
Selection for fodder -timber forest garden & 0.79 & 55,357 & \\
Selection for timber & & & \\
\hline
\end{tabular}

\section{Conclusion}

The silviculture trial plots establishment through the support and facilitation of EnLiFT in Kavre and Lamjung had played a key role in changing people's perspective in managing community forests for better livelihoods. Not only that the plots had served as practical learning grounds for basic forestry management and operations, but it also has produced hard data on the impact of silviculture interventions on forest and stand. It has been found that significant proportion of the canopy has been opened because of silviculture intervention, and these canopy gaps can be utilised to promote growth of timber and nontimber plants. Based on canopy gaps created, shelterwood and selection silviculture can be considered rigid stand intervention on Pine plantation while negative thinning is less rigid. For Sal-Chilaune forest however, it was found that regeneration development differs between silviculture treatments, although canopy gaps is almost similar. Although these results were not intended, negative thinning clearly created large gaps in a naturally regenerated forest compared to a Pine plantation. The reason for this is generally due to the higher number of stems of 4-D trees, generally Chilaune trees on Sal forests which are not present in Pine plantations. This is common in many Mid-hills Sal forests where older Chilaune and Sal trees are kept as mother trees despite the low phenotypic characteristics for mother trees. With government approval to conduct negative thinning, the FUG has been given clearance to remove the bad old trees in their forest.
Although it may be early to make conclusion from this regeneration development and canopy gap study as the stand is still undergoing some development due to silviculture operation. Moreover, silviculture operations have significant role in promoting higher regeneration and that rigid silviculture operations like selection and shelterwood systems are better than negative thinning.

\section{References}

Antinori, C and Rausser, G. 2008. Ownership and control in Mexico's community forestry sector. Economic Development and Cultural Changes 57 (1): 101-136.

Calderon, M. M., Nawir, A. A. 2006. An Evaluation of the Feasibility and Benefits of Forest Partnerships to Develop Tree Plantations: Case Studies in the Philippines. CIFOR Working Paper No. 27. Centre for International Forestry Research, Bogor, Indonesia.

Cedamon, E., Nuberg, I., Paudel, G., Basyal, M., Shrestha, K. and Paudel, N. 2017. Rapid Silviculture Appraisal to characterise stand and determine silviculture priorities of community forests in Nepal. Small-scale Forestry 16 (2): 195-218. DOI 10.1007/ s11842-016-9351-0.

Charnley, S. and Poe, M. 2007. Community forestry in theory and practice: where are we now? Annual Review of Anthropology 36: 
301-336.

Coates, K, and Burton, P. 1997. A gap-based approach for development of silvicultural systems to address ecosystems management objectives. Forest Ecology and Management 99 (3): 337-354.

Department of Forests. 2015. Scientific Forest Management Guidelines 2015. Department of Forests, Kathmandu, Nepal.

Dressler, W., Buscher, B. Schoon, M., Brockington, D., Hayes, T., Kull, C., McCarthy, J. and Shrestha, K. 2010. From hope to crisis and back again? a critical history of the global CBRNM narrative. Environmental Conservation 37 (1): 5-15

Gilmour, D. 2016. Forty Years of Communitybased Forestry: A Review of its Extent and Effectiveness. Food and Agriculture Organisation, Rome, Italy.

Jennings, S., Brow, N. and Sheil, D. 1999. Assessing forest canopies and understorey illumination: canopy closure, canopy cover and other measures. Forestry 72 (1): 59-73.

Khanal-Chhetri, B., Johnsen, F., Konoshima, M. and Yoshimoto, A. 2013. Community forestry in the hills of Nepal: determinants of user participation in forest management. Forest Policy and Economics 30 (5): 6-13.

Maryudi, A., Devkota, R., Schusser, C., Yufanyi, C., Salla, M., Aurenhammer, H., Rotchanaphatharawit, R. and Krott, M. 2012. Back to basics: considerations in evaluating the outcomes of community forestry. Forest Policy and Economics 14 (1): 1-5.
MFSC. 2016. Scientific Forest Management Initiatives in Nepal: MSFP Experiences and Lessons Learnt. Multi Stakeholder Forestry Program, Ministry of Forests and Soil Conservation, Kathmandu, Nepal.

Kern, C., Burton, J., Raymond. P., D’Amato, A., Keeton, W., Royo, A., Walters, M., Webster, C. and Willie, J. 2017. Challenges facing gap-based silviculture and possible solutions for mesic northern forests in North America. Forestry 90 (1): 4-17. (1) (1):4=17DOI:10.1093/forestry/cpw024.

O'Hara, K. 2002. The historical development of uneven-aged silviculture in North America. Forestry 75 (1): 339-346.

O’Hara, K. 2014. Multi-age Silviculture: Managing for Complex Forest Stand Structures. Oxford University Press, Oxford, UK.

Padgee, A., Kim, Y, Daugherty, P. 2006. What makes community forest management successful: a meta-study from community forests throughout the world. Society \& Natural Resources 19 (1): 33-52. DOI: 10.1080/08941920500323260

Pokharel, R. K. 2012. Factors influencing the management regime of Nepal's community forestry. For. Policy Econ. 17 (4): 13-17.

Sunderlin, W, Angelsen, A, Belcher, B, Burgers, P, Nasi, R, Santoso, L and Wunder, S. 2005. Livelihoods, forests and conservation in developing countries: an overview. World Development 33 (9): 1383-1402. 